レーザー解説

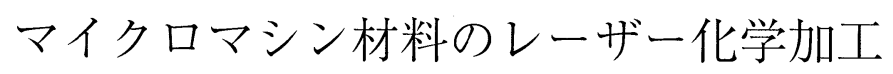

\title{
三澤 弘明*
}

（1996 年 4 月 26 日 受理)

\section{Laser-Induced Chemical Fabrication of Micromachine Materials}

\author{
Hiroaki MISAWA*
}

(Received April 26, 1996)

\begin{abstract}
Laser manipulation-microfabrication system consisting of a CW laser, a picosecond pulsed laser and an optical microscope was developed to assemble micrometer-sized structure in solution. Photopolymerization of reactive monomers induced at the focal spot of picosecond laser pulses $(\lambda=355 \mathrm{~nm}$ or $532 \mathrm{~nm}, \mathrm{FWHM}=30 \mathrm{ps}$, repetation rate $=10 \mathrm{~Hz})$ was employed for connection of glass particles regularly aligned by laser trapping. Since photopolymerization was induced in the vicinity of a focal spot, any desired numbers of glass particles with arbitrary geometrical structure can be connected by repeating the manipulation and the photopolymerization procedures.
\end{abstract}

Key Words: Laser microfabrication technique, Laser trapping, Photopolymerization, Picosecond laser pulse

1.はじめに

マイクロマシン技術の確立は，顕微鏡や内視 鏡を用いて行うマイクロサージェリーや人工臓 器などの先端医療技術の更なる発展に必要不可 欠であるといわれている。これは，医療が対象と している生体が, 組織や細胞から構成されてお り,さらにそれらはオルガネラと呼ばれるサブ マイクロメートルサイズの細胞内小器管からで きているため, 究極的な医療技術においては, そ れらを直接ハンドリングする手法の開発が必要
になるためである。

現在, マイクロマシンに関する研究は, シリコ ンなどの半導体微細加工技術を基軸とした研究 が活発に進められている。しかし, 半導体微細加 工技術は薄膜形成とエッチングという二次元微 細加工技術が基本であるため，立体的なマイク ロマシンを作製することは本質的に難しい。さ らに, 医療分野への応用を考えると, 半導体は生 体適合性などの面からマイクロマシンの材料と して最適なのか疑問が残る。また, 半導体を用い たマイクロマシンの場合, 主に電気的な駆動制

* 徳島大学工学部機械工学科（T 770 徳島市南常三島町 2-1）

* Department of Mechanical Engineering, Faculty of Engineering, University of Tokushima (2-1 Minamijosanjima, Tokushima 770) 
御が行われるものと考えられるが，配線から生 ずる電磁ノイズは筋肉の収縮などを誘発する危 険性もある。これらの問題を解決するためには, 新しいマイクロマシン材料と，その加工技術を 開発することが重要となる。

医療用マイクロマシン材料としては，すでに 医療分野で広く利用されている高分子材料が適 当であると考えられる。また，高分子材料を用い てマイクロマシンを作製する手法としては, 光 硬化性樹脂にレーザー光を照射し, 樹脂を生成 させて立体的な構造物を形成させる光造形法の 応用が有望である。しかし, 従来の光造形法は二 次元加工法であり，立体的なマイクロマシンの 加工を行うためには新しい三次元光造形法の開 発が必要不可欠である。

本稿に扔いては, 我々が医療用マイクロマシ ン作製技術の開発を目指して行っているレー ザー走査型マニピュレーション法と三次元光造 形法を用いた微粒子の接着, 連結, およびそれら の運動制御について紹介する。

\section{2. 光造形法}

現在，光造形法は生産開始前の製品の形状
チェックを行うためのプロトタイプの製作に広 い産業分野で用いられている1)。従来の光造形法 は光硬化性樹脂の液体界面にレーザー光を照射 し, 界面に形成する樹脂を積層させ，立体的な構 造物を作製する1)。最近，この光造形法をマイク ロマシン作製に応用し，微小構造物を作製する 試みがなされている2-5)。しかし，上述したよう に, この樹脂形成は二次元的であり, 加工分解能 も〜 $5 \mu \mathrm{m}$ 程度である ${ }^{4)} 。$

\section{3.レーザーマニピュレーション法の原理 6-8)}

物体によって光が屈折・反射すると放射圧と 呼ばれる応力が物体に働くが，レーザーマニ ピュレーション法はこの放射圧を利用して微小 物体を捕捉・操作する手法である。Fig. 1 にレー ザー光によって微粒子が捕捉されている様子を 示す。図中の光線 A について注目すると,レー ザー光は屈折率の異なる微粒子に入射すること により屈折し，光の運動量が入射前後で変化す る。さらに微粒子の中を通過した光は, 微粒子か ら出射するときにもう一度屈折し，入射時と同 様に運動量が変化する。変化した運動量は, 保存 則に従い微粒子に受け渡され，結果として微粒

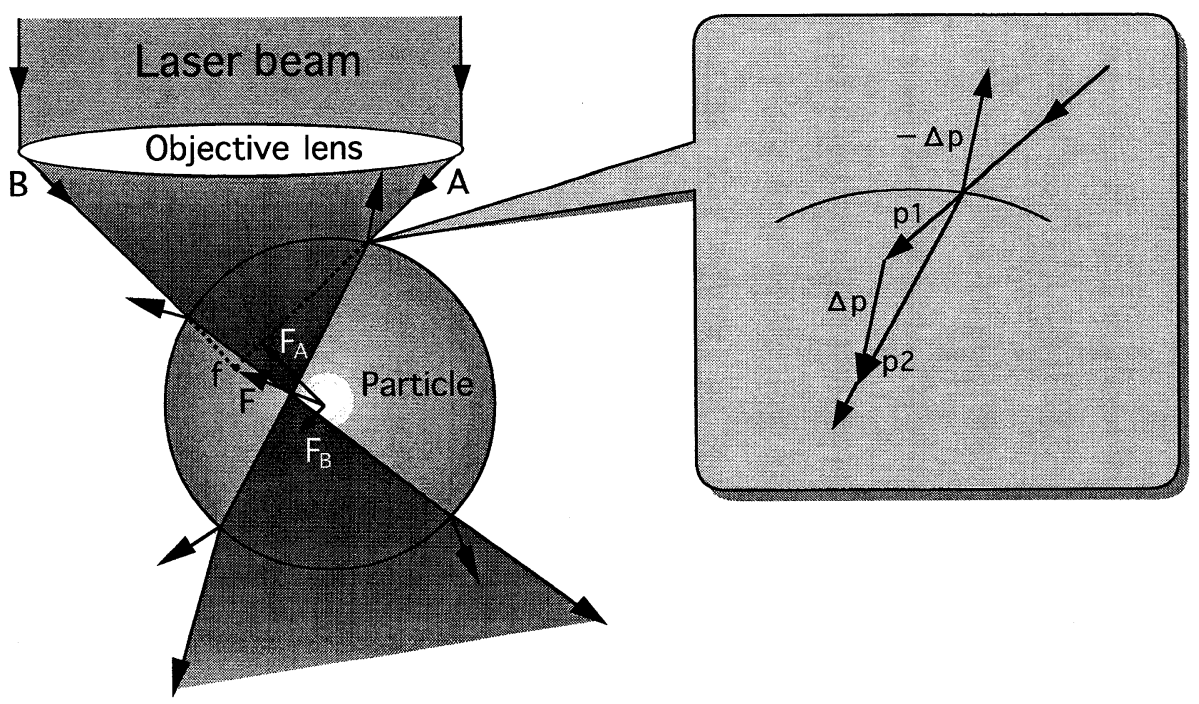

Fig. 1 Principle of laser trapping. 
子に放射圧 $\left(F_{\mathrm{A}}\right)$ が発生する。微粒子の屈折率が周 囲の媒質より高いときには, これらの力の和 $F$ は レーザー光の焦点位置の方向を向き, その力が 微粒子の熱運動を押さえ, 重力などの外力と釣 り合った位置で微粒子は捕捉される。レーザー 光の焦点位置を移動すれば捕捉されている微粒 子はそれに追従するため三次元的なレーザーマ ニピュレーションが可能である。我々は, この手 法をさらに発展させ, 捕捉レーザー光を高速に 走査するレーザー走査型マニピュレーション法 を開発した ${ }^{8)}$ ここれにより，単一微粒子のみなら ず複数の微粒子をレーザー光の走査パターン上 に配列したり ${ }^{9)}$ ，また，微粒子を移動させたりす ることも可能となった ${ }^{10)}$ 。

\section{4.レーザー走査マニピュレーション・加エシ ステムの構成 ${ }^{11)}$}

Fig. 2 に本研究に用いた装置の構成を示した。

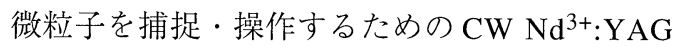

レーザー $(1064 \mathrm{~nm})$ は, 偏光ビームスプリッター により二つに分けられ, それぞれに2枚のガルバ ノミラーで2軸方向に偏光した。これらのビーム は再び偏光ビームスプリッターによって同軸に し, 顕微鏡の対物レンズ $(100 \times, N A=1.30)$ で 試料に集光した。ガルバノミラーはコンピュー 夕により制御されており，集光スポットを試料 の任意の位置に移動させたり，二次元的に走査 させて, 任意の図形を繰り返し描画することも 可能である。また，加工用のQ-スイッチモード ロック $\mathrm{Nd}^{3+}: \mathrm{YAG}$ レーザー（355 nm または 532

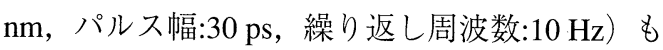
捕捉用レーザー光と同軸で顕微鏡に導入して試 料に照射した。微粒子のレーザーマニピュレー ションや接着・連結の様子はCCDカメラと TVモ ニターを用いて観測した。

\section{5. 二光子励起反応を利用した微粒子の接着}

高分子材料により立体的なマイクロマシンを

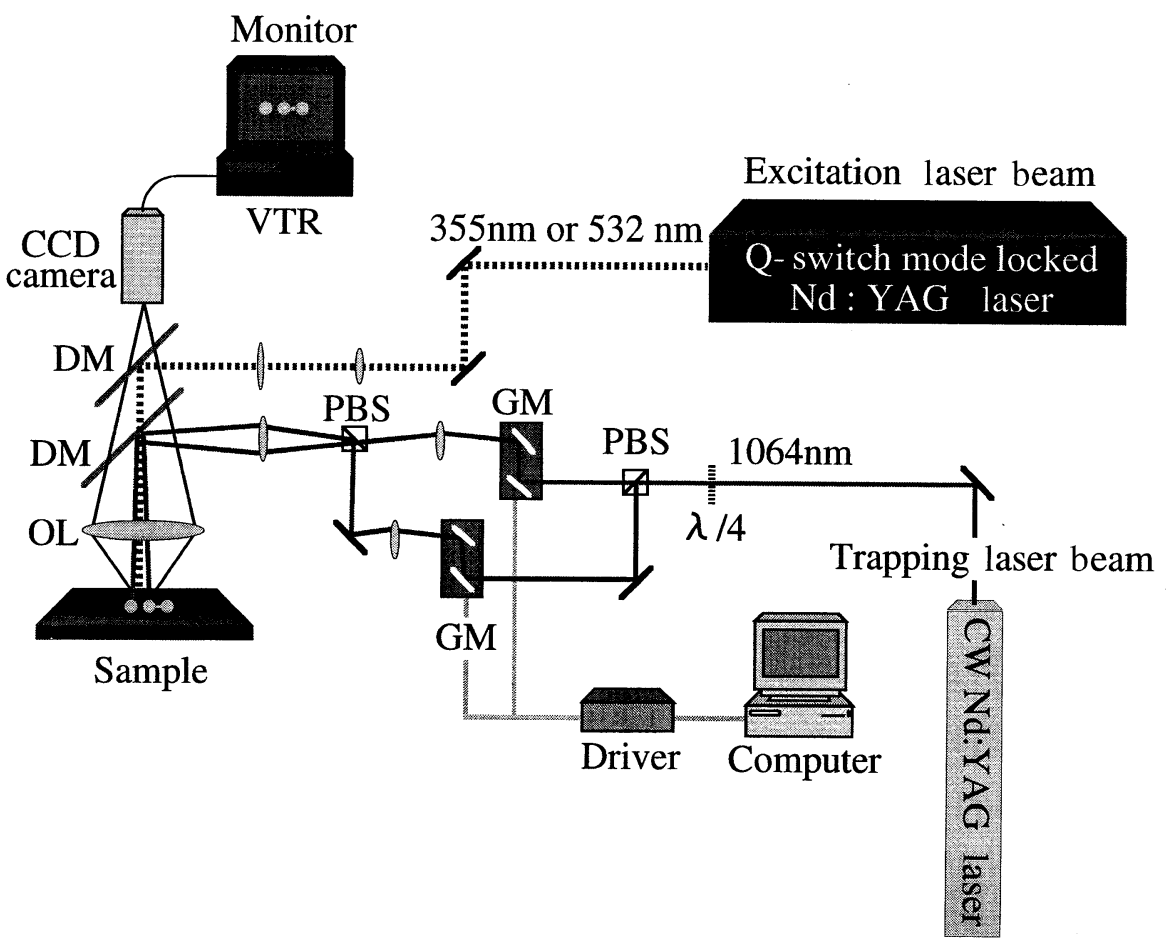

Fig. 2 Block diagram of the multi-beam laser manipulation-fabrication system. PBS, polarizing beam splitter; GM, galvano mirrors; DM, dichroic mirror; OL, objective lens. 
作製するためには従来の光造形法ではなく, 光 重合反応を空間選択的に誘起し, 三次元的に樹 脂形成を行う新しい光造形法の開発が必要とな る。このような空間選択的な光重合反応を誘起 する方法の一つとして, 多光子励起反応の利用 が考えられる。分子が一つの光子を吸収し反応 が進行する一光子反応は, 光照射した部分全て の空間において光化学反応が起きる可能性があ るため, 空間選択性を持たせることは難しい。し かし, 分子が複数の光子を同時に吸収し反応が 進行する多光子反応は, レーザー光強度の高い 空間に抒いてのみ分子が光を吸収するため, 焦 点付近において空間選択的に光反応を誘起する ことが可能になる12)。

我々は,このような視点から Fig. 2 に示した装 置を用いて光重合開始剤の多光子励起によって レーザー捕捉した 1 個のガラス微粒子の特定の部 位に選択的に高分子ゲルを生成させ，他のガラ ス微粒子との接着を試みた。試料としては, 光重 合開始剂である2,2-ジエトキシ-1-フェニルエ夕 ノン (DEPE, $\left.0.1 \mathrm{~mol} / \mathrm{dm}^{3}\right)$, 反応性モノマーであ るアクリル酸 $\left(\mathrm{AA}, 2.0 \mathrm{~mol} / \mathrm{dm}^{3}\right)$, 架橋剂である $\mathrm{N}, \mathrm{N}^{\prime}$ - メチレンビスアクリルアミド（MB A， $\left.0.1 \mathrm{~mol} / \mathrm{dm}^{3}\right)$ を含むエチレングリコール溶液に粒 径〜 $4 \mu \mathrm{m}$ のガラス微粒子を分散したものを用い た。まず，試料溶液中の 2 個のガラス微粒子を 2 本の捕捉用レーザー光 $(200 \mathrm{~mW})$ で独立に操作 し, 接触させた後, $532 \mathrm{~nm}$ のピコ秒パルスレー ザー光（レーザー高強度: $23 \mathrm{~J} / \mathrm{cm}^{2} /$ pulse）を照射 したところ約 60 秒後にはガラス微粒子を捕捉し ている2本のレーザー光を徐々に離しても微粒子 は互いに離れることなく, 微粒子が完全に接着 したことが確認できた。次に 2 本の捕捉用レー ザー光のうちの1本を接着した 2 個の微粒子の中 心を結ぶように走査し, この2 個の微粒子からな る構造物を 1 本の走査レーザー光のみで捕捉し た。もう一方の捕捉用レーザー光を用いて別の 微粒子を捕捉・操作し, この構造物に接触させ, 先と同様にその界面付近に励起用ピコ秒パルス レーザーを照射し, 3 個の微粒子からなる構造物 を作製した。同様な操作を繰り返し, Fig. 3 に示 した「L字型」の微粒子からなる構造物の作製に 成功した13)。この接着は, ポリアクリル酸ゲル

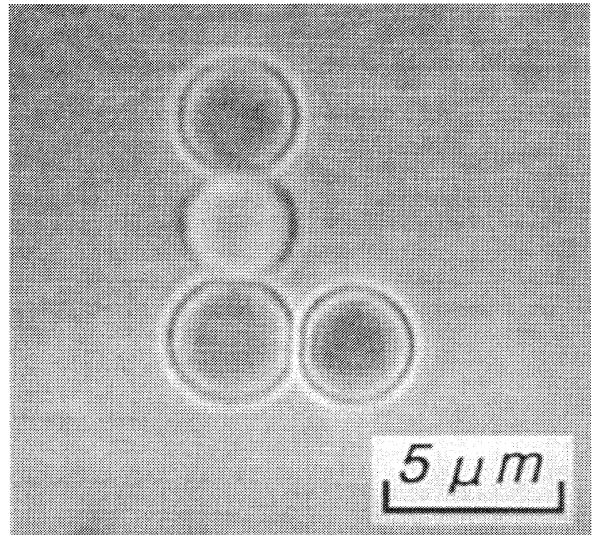

Fig. 3 Assembling of glass beads in ethylene glycol by multi-photon excitation induced polymerization.

の生成によって生じたものと考えられるが, DEPEの吸収带が $532 \mathrm{~nm}$ 付近に全く存在しない ことから, 少なくとも二光子以上の光励起に よってこの光重合反応が誘起されたものと考え られる。

一方, 同様の方法により 10 分間ピコ秒パルス レーザー光をガラス微粒子の特定部位に照射し たが, 通常の光造形法にみられる樹脂の形成は 観測できなかった。これは, DEPEの二光子吸収 の吸収断面積が小さく, 効率よく光重合反応を 誘起できないためと考えられる。

\section{6. 一光子励起反応を用いた三次元光造形法に よる微粒子の連結 ${ }^{14)}$}

前述した二光子励起の場合と同様に, Fig. 2 に 示した装置を用い, 光重合開始剤の一光子励起 によって三次元的に樹脂を形成させる試みを 行った。試料としては, 光重合開始剤として4,4'ジヒドロキシベンゾフェノン（DHBP， $0.8 \mathrm{~mol} /$ $\left.\mathrm{dm}^{3}\right)$, 反応性モノマーであるアクリル酸 ( $\mathrm{AA}$, $\left.2.0 \mathrm{~mol} / \mathrm{dm}^{3}\right)$, 架橋剤である $\mathrm{N}, \mathrm{N}^{\prime}-$ メチレンビ,スア クリルアミド $\left(\mathrm{MBA}, 0.03 \mathrm{~mol} / \mathrm{dm}^{3}\right)$ を含むエチ レングリコール溶液に粒径〜 $4 \mu \mathrm{m}$ のガラス微粒 子を分散したものを用いた。また, 市販の光硬化 性樹脂であるノプコキュア 800 (サンノプコ (株)）に同様の粒径のガラス微粒子を分散させ 

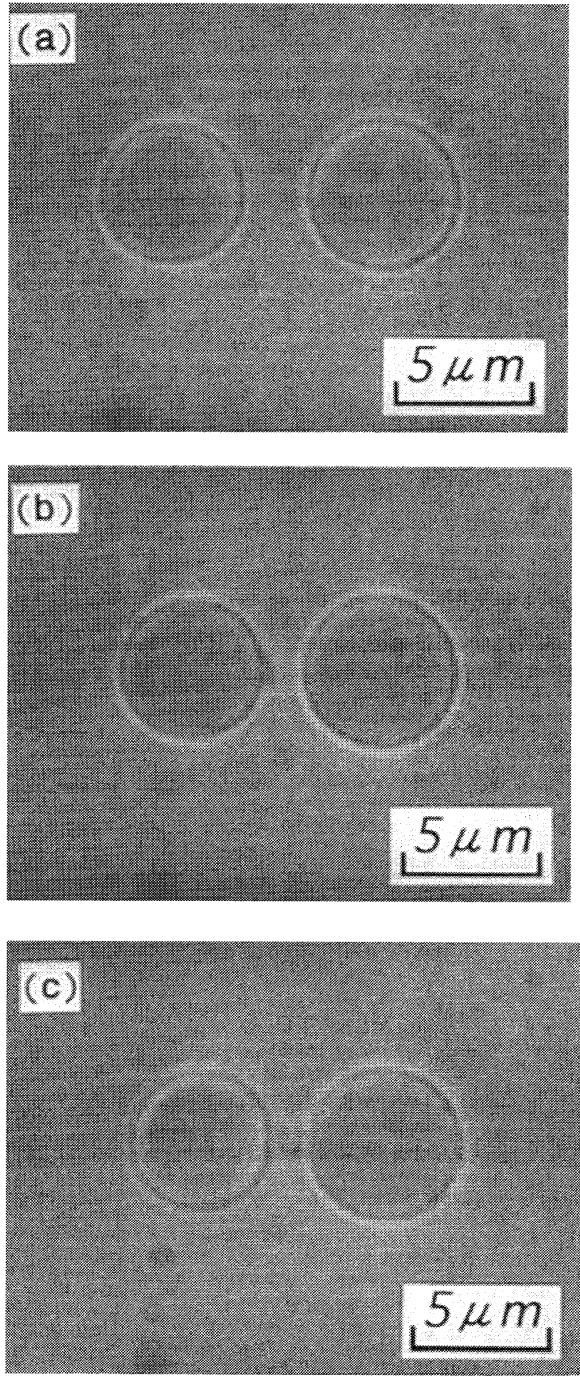

Fig. 4 Connecting of optically trapped glass beads by laser-induced direct-write polymerization.

た溶液も用いた。

Fig. 4にDHBPを含む溶液を用いた場合の結果 を示した。まず，2個のガラス微粒子を 2 本の捕 捉用レーザー光 $(300 \mathrm{~mW})$ によりそれぞれ捕捉 した（Fig. 4(a)）。一方の微粒子の界面近傍に $355 \mathrm{~nm}$ のピコ秒パルスレーザー光（レーザー高 強度: $24 \mathrm{~J} / \mathrm{cm}^{2} /$ pulse）を照射したところ, 約 10 秒 後に焦点付近からポリアクリル酸ゲルが形成す るのが観測された (Fig. 4(b))。さらに，レーザー
光の焦点位置をもう一方の微粒子の方向へ徐々 に移動させることによりゲルを成長させ，それ ぞれのガラス微粒子をゲルによって連結させる ことに成功した (Fig. 4(c))。ガラス微粒子を捕捉 している2本のレーザー光を徐々に離しても微粒 子と生成したゲルは分離することはなかった。 粒径〜 $4 \mu \mathrm{m}$ のガラス微粒子は, 用いた試料溶液 中で $300 \mathrm{~mW}$ の捕捉用レーザー光により，光軸と 垂直方向に190ピコニュートン $(\mathrm{pN})$ の捕捉力に よって捕捉されることが別の実験によって確認 されている。従って，このガラス微粒子とポリア クリル酸ゲルとの接着力は $380 \mathrm{pN}$ 以上であるこ とが示された。

ポリアクリル酸ゲルの生成初期過程において は, DHBPの最低励起三重項状態からの水素引き 抜き反応が存在すると考えられる。一般的にガ ラス表面はOH基によって覆われていると考えら れているが，このOH基の水素原子を引き抜くこ とは困難であり，反応は溶媒として用いている エチレングリコールの2級水素を引き抜くことに よって開始するものと考えられる。従って, ガラ ス微粒子とポリアクリル酸ゲルとの接着は化学 的なものではなく，光学顕微鏡では観測するこ とができないガラス微粒子表面のナノメートル サイズの凹凸において形成したゲルによる物理 的なものであると結論できる。

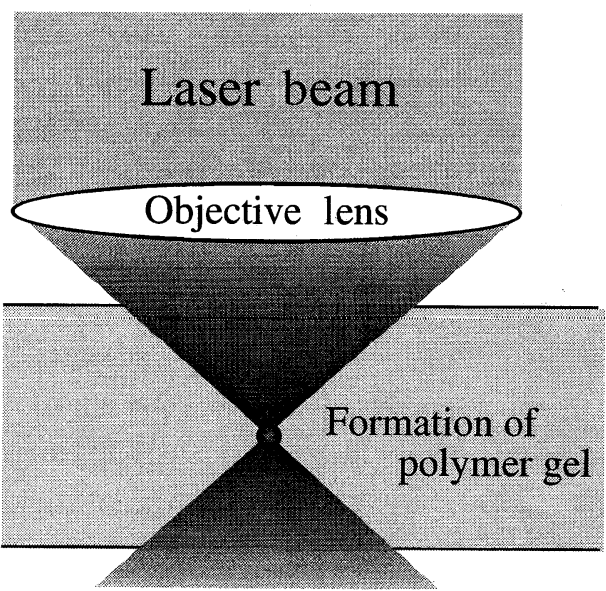

Fig. 5 Principle of three-dimensional direct-write polymerization by a one-photon excitation process. 

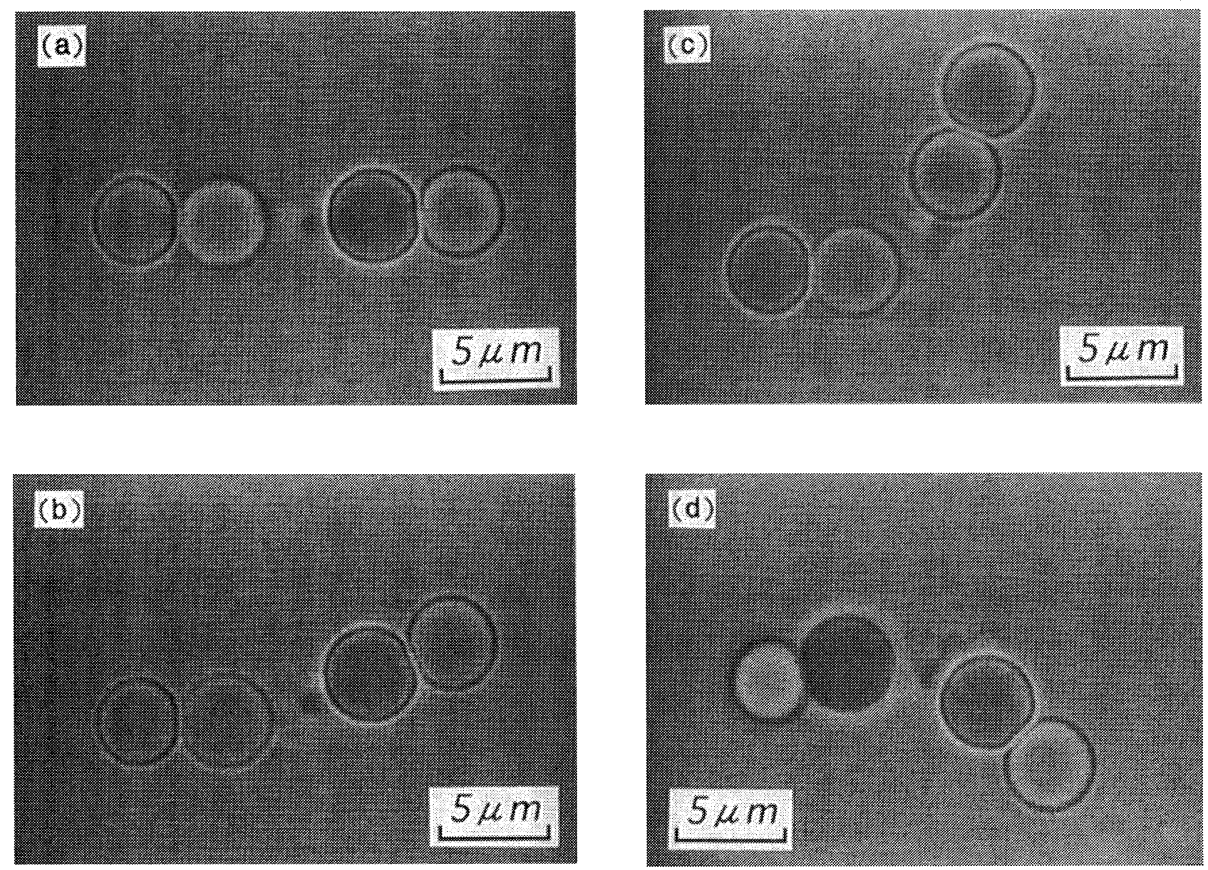

Fig. 6 Buckling of microstructure consisting of glass beads and polyacrylic acid gel by optical trapping force.

このように，一光子励起反応によっても三次 元的に高分子ゲルを形成させることが可能であ ることが明らかとなった。これは, 用いた対物レ ンズの NAが 1.30 と大きく, レーザー光が Fig. 5 に示すように極めて急峻に絞られた状態で試料 に照射されるため, 焦点付近の光子密度が他の 部分と比べて極端に高くなり，そのため焦点付 近にのみゲル化反応が誘起されたものと考えら れる。

このような三次元的な光造形法を用いてFig. 6 (a)に示したガラス微粒子 4 個からなる微小構造 物を作製した。このガラス微粒子の両端を 2 本の レーザー光によって捕捉し, 一方のレーザー光 の位置を固定し, 他方のレーザー光を移動させ ると, 連結部のポリアクリル酸ゲルの屈曲が観 測された（Fig. 6(b), (c), (d))。

また,ノプコキュア $800 を$ 用いた場合も同様の 方法によりパルスレーザー光（レーザー高強度： $14 \mathrm{~J} / \mathrm{cm}^{2} /$ pulse）を照射し，3個の微粒子の連結に 成功した (Fig. 7)。連結部の加工分解能は, 光軸 と垂直方向で約 $1 \mu \mathrm{m}$, 光軸方向では $4 \mu \mathrm{m}$ 以下で あることが確認された。ノプコキュア 800 は，上

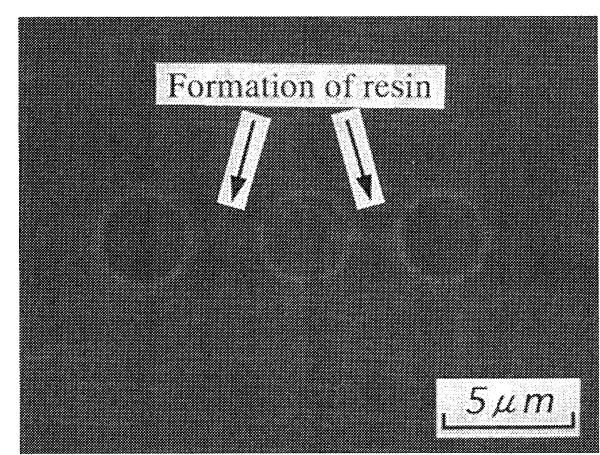

Fig. 7 Connecting of optically trapped glass beads by laser-induced direct-write resin formation.

述した高分子ゲルとは異なり，パルスレーザー 照射後 1 秒以内に樹脂が生成した。また，生成し た樹脂は極めて剛直であり，捕捉用レーザー光 によって屈曲させることはできなかった。

\section{7. おわりに}

レーザー走査型マニピュレーション法と新し い三次元的な光造形法を用いて, 複雑な過程を 経ることなしに微粒子の接着や連結に成功した。 
さらに，剛直な微小構造物や柔軟でレーザーマ ニピュレーション法により屈曲運動が可能な微 小構造物など，用いる高分子材料により様々な 性質を持つ微小構造物を作製することが可能で あった。今後, 本手法を用いて複雑な立体的形状 を有するマイクロマシンの作製を行っていきた いと考えている。

本研究の推進に日頃協力していただいている 研究室の堀山 真氏に心から感謝の意を表した w。

\section{参 考 文 献}

1) 丸山洋二, 大川和夫, 早野誠治, 斉藤直一郎, 中井 孝: 光造形法 (日刊工業新聞社, 東京, 1990).

2) H. Misawa, K. Sasaki, M. Koshioka, N. Kitamura and H. Masuhara: Appl. Phys. Lett. 60 (1992) 310.

3) H. Misawa, K. Sasaki, M. Koshioka, N. Kitamura and H. Masuhara: Macromolecules 26 (1993) 282.

4) K. Ikuta and K. Hirowatari: Proc. of IEEE Micro Electro Mechanical Systems '93 (1993) p. 42.
5) T. Takagi and N. Nakajima: Proc. of IEEE Micro Electro Mechanical Systems '94 (1994) p. 211.

6) A. Ashkin: Science 210 (1980) 1081.

7) A. Ashkin and J. M. Dziedzic: Ber. Bunzen-Ges. Phys. Chem. 93 (1989) 254.

8) K. Sasaki and H. Misawa: Microchemistry-Spectroscopy and Chemistry in Small Domains (Elsevier, Amsterdam, 1994) p. 23.

9) K. Sasaki, M. Koshioka, H. Misawa, N. Kitamura and H. Masuhara: Jpn. J. Appl. Phys. 30 (1991) L 907.

10) K. Sasaki, M. Koshioka, H. Misawa, N. Kitamura and H. Masuhara: Opt. Lett. 16 (1991) 1463.

11) 増原宏, 喜多村曻, 三澤弘明, 玉井尚登, 笹 木敬司:マイクロ化学(化学同人, 京都, 1993) 第 2 章。

12) 三澤弘明 : 化学と工業 2 (1996) 178.

13) 堀山 真, 三輪昌史, 三澤弘明: 日本化学会第 69 春季年会講演予稿集, (1995 年 3 月) p. 646.

14) 堀山 真, 三輪昌史, 三澤弘明: 日本機械学会 第73期通常総会講演会講演論文集(IV), (1996 年 4 月) p. 472.

\section{レーザーワード}

微小球レーザー発振 (microspherical lasing)

表面張力によって極めて高い真球度が得られる高分子ラテックス, 微小液滴，ガラスビーズなどの マイクロメートルオーダーの球形微粒子は，104 $10^{8}$ といった高い $\mathrm{Q}$ 值を持つ光共振器としての働 きがあり，色素をドープしてポンプするとレーザー発振を誘起することができる。 Whispering gallery mode resonances とも呼ばれるこの微小球共振現象は, 1984年, Tzengらによって微小液滴のレーザー 発振が観測されて以来, その物理的特性の理論的, 実験的研究が活発に進められている。また, 常温 光化学ホールバーニング, 微粒子分光, 近接場顕微鏡プローブなどへの応用も試みられている。

(笹木 敬司)

\section{光熱分光法 (photothermal spectroscopy)}

一般に分子が光励起されるとほぼ必ず物体の温度が上昇する。この発熱を捕えることでその系のさ まざまな性質を知ることを目的とした分光法が光熱分光法である。温度上昇を直接検出する方法, 熱 膨張による音波として捕らえる方法, 屈折率変化として測定する方法, 黒体輻射を検出する方法など がある。この手法は非常に高感度であること, 光の透過しない試量でも吸収などが測定できること, スペクトルは種々の緩和過程の速度に依存することなどの特色をもち, レーザーなどの光源の進歩と 共に, 高感度微量分析や非破壊分析, 診断, 物理化学的な緩和過程の研究, 光化学反応の研究などに 急速に用いられる様になってきた。一方, 最近では強力なレーザー光を用いたとき発生する熱や音波 のために光学系がダメージを受けることがしばしばあり，こうした問題を克服するための検出手段と しても応用される。 (寺嶋 正秀) 